\title{
The Assessing Credit Risk Management Practice of MFIs: Evidence from Micro Finance Institutions in Sidama Regional State, Ethiopia
}

\author{
Kanbiro Orkaido Deyganto \\ Department of Accounting and Finance, Furra College Gudamale Campus, Furra Institute of Development \\ Studies and Education, Hawassa, Ethiopia
}

\begin{abstract}
Sound credit risk management practices in the MFIs industry enables to control an institution's exposure to losses and protect the value of its assets by improving the loan collection. So, the objective of this study was to identify effect of credit risk management practice on loan collection of MFIs in Sidama regional state, Ethiopia. To this end, the researcher employed quantitative approach with explanatory research design where the effect caused by the independent variables on the dependent variable is observed through regression analysis. The purposive sampling techniques has been employed by researcher in order to select 115 sample size from five MFIs in the study area. The primary data was collected using structured questionnaire. Then, both descriptive and inferential statistics analyses have been done through SPSS version 21.0 in order to get the reliable research findings. Accordingly, the result of multiple liner regression showed that five variables such as use of collateral, credit risk identification, credit monitoring, credit policy and credit analysis have positive and statistically significant effect loan collection. Based on the findings of the study, the researcher forwarded possible recommendations for the MFIs in the study area to work on statistically significant variables due to fact that they have significant influence in improving loan collection. For instance, increase on the use of collateral increase in loan collection. This implies that more the institutions ask for collateral before lending money for borrowers contributes to the effectiveness loan collection practice. So, that it is recommended to Sidama Chalala should work on collateral to improve loan collection that enables to advance the capacity of MFIs to deliver different financial services to the lower income people.
\end{abstract}

Keywords: Credit Risk Management Practice, Loan Collection, Micro Finance Institutions, Sidama Regional State, Ethiopia

DOI: $10.7176 / \mathrm{EJBM} / 12-19-03$

Publication date:July $31^{\text {st }} 2020$

\section{Introduction}

According to [3] and [1] microfinance is a provision of a broad range of financial services such as savings, credit, insurance and payment services to the poor or low-income group who are excluded from the normal banking sectors. In other way, microfinance covers the provision of a range of financial services to low income households, including loans, savings, money transfers and insurance. The microfinance revolution has allowed more than 150 million poor people around the world to receive small loans without collateral, build up assets, and buy insurance. The idea that providing access to reliable and affordable financial services can have powerful economic and social effects has captured the imagination of policymakers, activists, bankers, and researchers around the world; the 2006 Nobel Peace Prize went to microfinance pioneer Muhammed Yunis and Grameen Bank of Bangladesh[17].

In developing countries, like Ethiopia, micro financing institutions (MFIs) emerged with unique opportunity to serve poor people who do not have access to commercial banks. Microfinance involves the provision of microcredit, savings, and other services to the poor that are excluded by the commercial banks for collateral and other reasons. Microfinance programs and microfinance institutions have augmented in outreach over the last few years with their largest client being the poor, vulnerable and women [27].

Microfinance institutions are one of the financial institutions which provide different financial service for the poor who are out of the conventional banking system particularly in developing countries of the world including Ethiopia. It has been renowned globally as a feasible and sustainable tool for poverty reduction and economic development through improving income generating activities and employment creations. Micro-Finance Institutions (MFIs) can be defined as any activity that includes the provision of financial services such as credit, savings, and insurance to low income individuals which fall just above the nationally defined poverty line, and poor individuals which fall below that poverty line, with the goal of creating social value. The creation of social value includes poverty alleviation and the broader impact of improving livelihood opportunities through the provision of capital for micro enterprise, insurance and savings for risk mitigation and smoothing [1].

MFIs established in 1996 and comprises the Commercial Code of Ethiopia, proclamations issued by Government of Ethiopia (GOE) based on the Proclamation No. 40/1996, and Proclamation No. 147/1998) directives issued by the National Bank of Ethiopia (NBE). Microfinance Institutions are required to incorporate as 
share companies in accordance with the provisions of Article 304 of the Commercial Code of Ethiopia. According to Association of Ethiopia Micro Finance Institution currently there are 35 Micro Finance Institutions operating in different regional states of Ethiopia. Among them five (5) MFIs were operating in Sidama Regional States. They are; Sidama Microfinance, Omo Micro Finance, Agar Microfinance, Vision Fund Micro Finance, and Kendile Micro Finance. As any organization credit provision practice is necessary for the efficiency and effectiveness of Micro finance operation. An effective credit provision function provides independent assurance to the board of directors and senior management on the quality and effectiveness of MFI $^{\text {ee }}$ s credit risk management and governance systems and processes, a strong internal control system, including an independent and effective internal audit function, is part of sound corporate governance. Having the an sound credit provision practice provides vital assurance to an organization's in doing so, the function helps reduce the credit risk and enables easily collect loan.

The study by [16] revealed that the Microfinance institutions in Ethiopia were influenced by constraints such poor credit risk management. Besides, the finding study by [2] credit risk continues to has become the threat to Microfinance Banks sustainability because it limits the loan collection capacity of Microfinance Institutions. This is why credit risk management practice of micro finance institutions and its effect on loan collection has becomes burring issue that demands scientific investigation.

Credit risk provision practice of micro finance institutions is one of the most important activities that cannot be overlooked by any micro finance institutions irrespective of its business nature. Sound credit risk management is a prerequisite for a financial institutions stability and continuing profitability, while deteriorating credit quality is the most frequent cause of poor financial performance and condition. As with any financial institution, the biggest risk in microfinance is lending money and not getting it back [29]. Credit risk management is a structured approach to managing uncertainties through risk assessment, developing strategies to manage it and mitigation of risk using managerial resources. The strategies include transferring to another party, avoiding the risk, reducing the negative effects of the risk, and accepting some or all of the consequences of a particular risk. Effective credit risk management is the process of managing an institution's activities which create credit risk exposures, in a manner that significantly reduces the likelihood that such activities will impact negatively on a bank's earnings and capital. Credit risk is not confined to a bank's loan portfolio, but can also exist in its other assets and activities. Hence, this study is designed to examine the credit provision practice Micro Finance Institutions in in Sidama regional states and its effect on loan collection.

\subsection{The objectives of the study}

The General Objective of this study is to assess the practice of credit provision and its effect on loan collection of Micro Finance institutions in Sidama regional state, Ethiopia. In line with general objective, this study has addressed the following specific objectives:

a) To examine the effect of use collateral on loan collection

b) To investigate the effect of credit risk identification on loan collection

c) To identify the effect of credit monitoring practices on loan collection

d) To investigate the effect of credit policy on loan collection

e) To explore the effect of credit risk analysis on loan collection

\subsection{Research Hypothesis}

After reviewing empirical studies related to the topic, the researcher has developed the following tentative statements to be proved by regression analysis: these are as follow:

H1: A use of collateral has positive and statistically significant effect on loan collection

$\mathrm{H} 2$ : A Credit risk Identification has positive and statistically significant effect on loan collection

H3: A Credit monitoring has positive and statistically significant effect on loan collection

H4: A Credit policy has positive and statistically significant effect on loan collection

H5: Credit risk analysis has positive and statistically significant effect on loan collection

\subsection{Significance of the Study}

The end result of this study is expected to benefit to the micro finance institutions in Sidama regional state primarily and to the governing organ of the financial institutions national bank of Ethiopia, policy makers and the government, the public at large and the investors, researchers who want to further investigate similar issues. The result of the analysis is expected to be supportive of designing well studied credit provision practice which strengthen the trial of loss minimization by the respective organizations including the micro finance institutions.

\section{Review of Related Literature}

\subsection{Overview of Microfinance and Credit Risk}

Microfinance is a category of financial services targeting individuals and small businesses who lack access to conventional banking and related services. Microfinance includes microcredit, the provision of small loans to poor 
clients; savings and checking accounts; micro insurance; and payment systems, among other branches [22]. So, microfinance services are designed to reach excluded customers, usually poorer population segments, possibly socially marginalized, or geographically more isolated, and to help them become self-sufficient [1].

The formal financial institutions played little role in financing development efforts in the rural areas. This is because they are clustered in urban areas, concentrate on funding large enterprises and are inaccessible to the rural poor especially in terms of distance. In addition, the rural poor can't fulfill banking requirement to get credits. The requirements for collateral and intrinsic banking procedures are in most cases very difficult for the poor to deal with. The volume of loan demanded by small farmers is not appealing to banks. Such loans are difficult to manage and their processing not financially feasible [3].

The Microfinance Institutions are targeted towards providing smaller loans to the mass, have been operating in the country for long towards satisfying the credit demand of the lower class of the economy, mainly composed of the informal sector. Meanwhile, credit risk is the most important of the risk categories. It is the potential loss resulting from the poor quality of the MFIs assets particularly its credit/loan portfolio. The most obvious manifestations of risk in credit projects are poor portfolio quality that leads to bad debt losses that erode the capital of the lending microfinance institution. The major variable that should determine a MFI's risk classification system are: past and present experience with overdue payments and type of methodology used in delivering loans [16].

Credit risk is directly related to the portfolio of the organization and is one of the most significant risks from an MFI perspective. Whenever an MFI lends to a client there is an inherent risk of money not coming back, i.e. the client turning into a defaulter, this risk is called the Credit risk. Credit risk is simply the possibility of the adverse condition in which the clients does not pay back the loan amount [9].

According to [5] credit risk, the most frequently addressed risk for MFIs, is the risk to earnings or capital due to borrowers' late and non-payment of loan obligations. Credit is a borrowed fund with specified term for repayment. The major issues raised in connection to credit provision are: loan size, loan term, interest rate, and grace period. Loan size is one of indicator of the depth and width of outreach in micro finance institutions and credit risk one major issue that harms the credit provision practice of MFI [15].

\subsection{Empirical Review of Related Studies and Hypotheses Development}

Reviewing of Empirical literature will provides a summary of some of the published work on the management of risks by banks in developed and developing economies. To this end, Prior researchers like [2],[3], [16] [4], [18];[25],[27], and studied the topic and suggest that, use of collateral, credit risk monitoring credit policy, credit risk identification, and credit risk analysis were essential tools of credit provision practice controlling tools have statistically significant influence the loan collection. But, they do not classify the explanatory variables in relation to any aspect in relation to Micro finance Institutions. But, the student researcher incorporated the credit provision practice related factors as independent variables and loan collection as dependent variables in the model. Loan collection is dependent variable of this study. The effective Loan collection System of MFIs is influenced by the following factors. This are reviewed and hypothesized as follow:

\section{1) Using of Collateral:}

The collateralization of loan is a mechanism for ensuring the repayment of loans other than the provision of formal collateral by the borrower. According to the regression result of empirical study by [3], [4]; [18] and [25] showed that use of collateral has positive influence on effect on loan collection

H1: A use of collateral has positive and statistically significant effect on loan collection

\section{2) Credit Risk Identification (CRI):}

In order to properly manage risks, an institution must recognize and understand risks that may arise from both existing and new business initiatives. Properly identified credit risk enables to easily manage the risk and ensures credit collection. . According to the regression result of empirical study by [10], [21]; [23]; [25] and [23] showed that credit risk identification has positive influence on effect on loan collection

H2: A Credit Risk Identification has positive and statistically significant effect on loan collection

\section{1) Credit Monitoring (CM):}

Monitoring reports should be frequent, timely, accurate, and informative and should be distributed to appropriate individuals to ensure action, when needed. After measuring credit risk, an institution should establish and communicate risk limits through policies, standards, and procedures that define responsibility and authority. Accordingly, [3], [4], [18], and [25] result indicated that credit monitoring has positive loan collection. Therefore, the researcher has forced to hypothesize that:

H3: A Credit monitoring has positive and statistically significant effect on loan collection

2) Credit Policy (CP):

It is a set of guidelines that are used to determine which customers are extended credit and billed. Set the payment terms for parties to whom credit is extended. Define the limits to be set on outstanding credit accounts. Good lending policy has positive influence on credit collection of MFIs while poor credit policy has positive consequence on credit collection. Hence, [3], [4], [11]; [18], [19], [20], [21] and [25] result indicated that credit 
policy has positive effect on loan collection.

H4: A Credit policy has positive and statistically significant effect on loan collection

3) Credit Risk Analysis (CRA):

After risk identification, analysis should follow, this will provide a greater understanding of risk, and is important to the organization as it helps in making risk based measureable and be aware about credit risk and easily manage it. Hence, [3], [4], [11]; [18], [19], [20], [21], [23], [25], [26], [27]; [28] and [29] result indicated that credit policy has positive effect on loan collection.

H5: Credit Risk Analysis has positive and statistically significant effect on loan collection

\subsection{Conceptual framework of the study}

A conceptual framework is an analytical tool with several variations and contexts. It can be applied in different categories of work where an overall picture is needed. It is used to make conceptual distinctions and organize ideas. Strong conceptual frameworks capture something real and do this in a way that is easy to remember and apply. In research context, it shows the independent variables such as use of collateral, credit risk identification, credit monitoring, credit policy and credit risk analysis as independent which have positive and statistically significant effect on dependent variable which is loan collection of micro finance institutions operating in Sidama Regional State, Ethiopia.

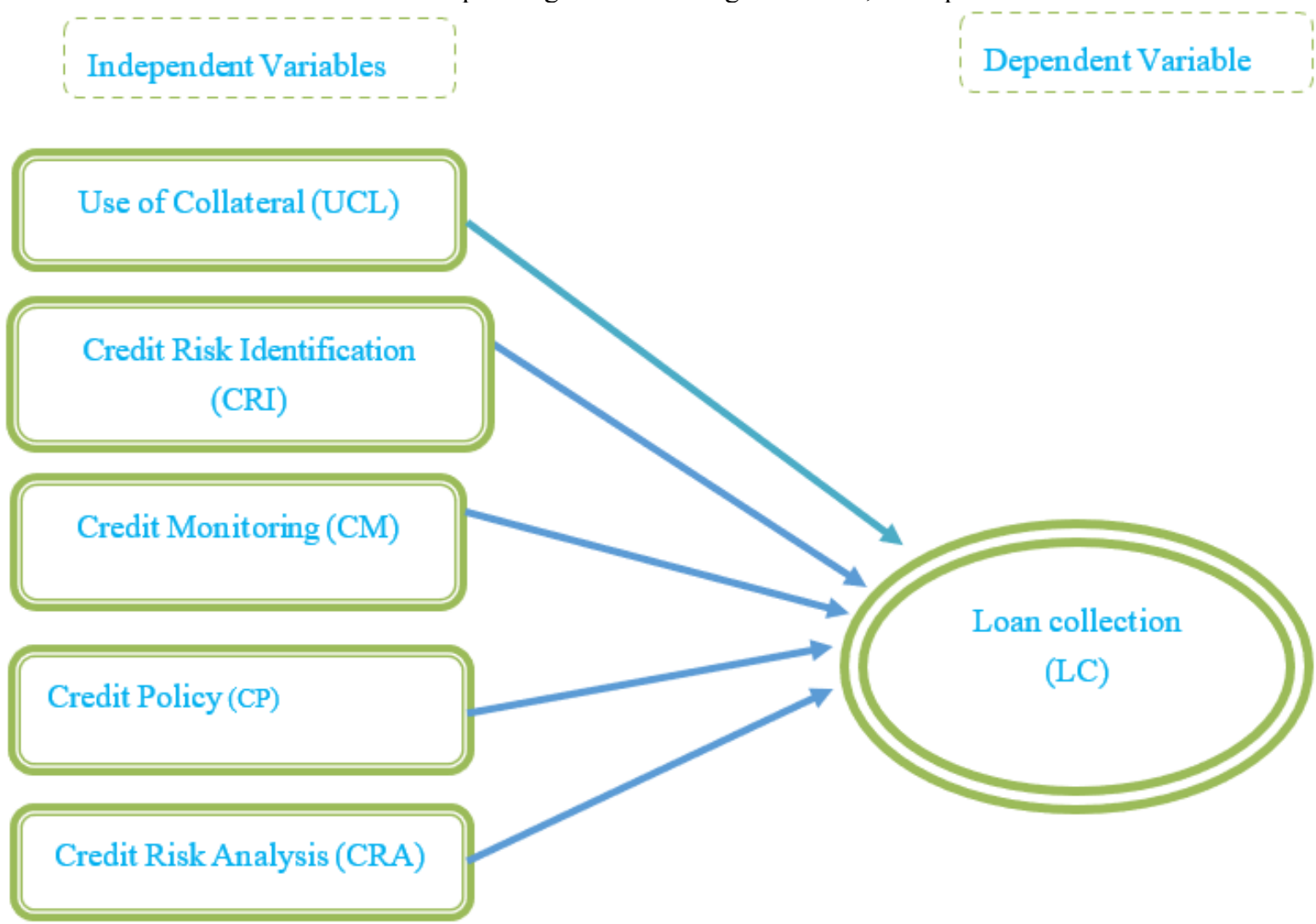

Source: Own construct based on literature review (2020)

\section{Materials and Methods}

\subsection{Research Design and Approach}

In this study, the researcher was employed explanatory study design to precede this specific study because the objective of this study is to identify the effect of credit provision practice on loan collection of MFIs in Sidama Regional State. The research approach of this study was quantitative research approach due to quantitative nature of data used to prepare the report of this study.

\subsection{Data source and Methods of Data Collections}

In this research, the researcher used both primary and secondary data. The source of primary data was collected from respondents selected from the MFIs. While the secondary data source were collected from published materials like journals, books, and conference proceedings and unpublished like office annual reports, minuets and other materials related to the study. To collect primary data structured questionnaire was used. 


\subsection{Target Population, Sample Size and Selection Techniques}

The target population of this study were all Microfinance Institutions Found in Sidama Regional State. Currently there are 5 Microfinance Institutions Operating in Sidama Regional State. They are Omo Micro Finance, Sidama Micro Finance, Vision Fund Micro Finance, Agar Micro Finance and Kendile Micro Finance. These are considered as the target population of the study by the student researcher. To draw targeted respondent that means sample size from those MFIs this study was used judgmental sampling methods which is non-probability sampling techniques. To assess the credit provision practice and its effect on loan collection of Micro finance Institution operating in the region. The main respondents included directors (management members), loan officers, internal auditors and fiancé heads who serve in those MFIs. This is with the aim of getting detail about the topic under study and these respondents are considered to have direct relationship with their activity in their organization. Targeted population was 100 loan officers, 20 internal auditors, 34 managers and 5 finance heads from each MFIs total 159. Who were serve in the study MFIs. Respondents were selected purposively due to their proximity to the research objectives

Table 3.1: List of MFIs Operating in Sidama Regional State, Targeted population and Targeted

Sampled respondents

\begin{tabular}{|c|c|c|c|c|c|c|c|}
\hline \multirow{2}{*}{$\begin{array}{c}\text { Serial } \\
\text { Number }\end{array}$} & \multirow[b]{2}{*}{ List of MFIs } & & & & & \multirow[b]{2}{*}{ 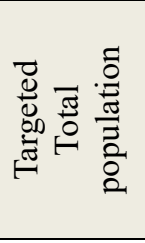 } & \multirow[b]{2}{*}{ 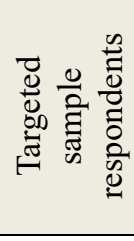 } \\
\hline & & 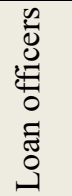 & 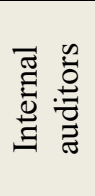 & 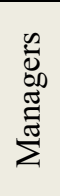 & 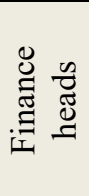 & & \\
\hline 1 & Omo Micro Finance (OMFI) & 50 & 6 & 9 & 1 & 66 & 50 \\
\hline 2 & Sidama Micro Finance (SMFI) & 24 & 4 & 10 & 1 & 39 & 25 \\
\hline 3 & Vision Fund Micro Finance (VFMFI) & 12 & 4 & 8 & 1 & 25 & 20 \\
\hline 4 & Agar Micro Finance (AGMFI) & 8 & 2 & 1 & 1 & 12 & 10 \\
\hline 5 & Kendile Micro Finance (K MFI) & 6 & 4 & 6 & 1 & 17 & 10 \\
\hline & Total & 100 & 20 & 34 & 5 & 159 & 115 \\
\hline
\end{tabular}

Source: Researchers' Own survey from study MFIs in (2020)

Hence, the representative sample size of this study is 115 respondents for obtaining primary data required for this study.

Table 3.2: Measurement of dependent and independent variables

\begin{tabular}{|c|c|c|c|}
\hline Variables & Symbol & Measurement & $\begin{array}{c}\text { Expected } \\
\text { Sine }\end{array}$ \\
\hline loan collection & LC & 5 point Likert scale questionnaire & + \\
\hline Use of Collateral & CL & 5 point Likert scale questionnaire & + \\
\hline Credit Risk Identification & CRI & 5 point Likert scale questionnaire & + \\
\hline Credit Monitoring & CM & 5 point Likert scale questionnaire & + \\
\hline Credit policy & CP & 5 point Likert scale questionnaire & + \\
\hline Credit Risk Analysis & CRA & 5 point Likert scale questionnaire & + \\
\hline
\end{tabular}

Source: Own Construct (2020)

\subsection{Econometrics Model Specification}

In this study, loan collection of MFIs is continuous variable that can be measured through multiple linear regression model. In the multiple linear regression model, the dependent variable loan collection (LC) and five independent variables such (1) use of collateral (2) Credit Risk Identification (CRI), (3) Credit Monitoring (CM), (4) Credit policy (CP), and (5) Credit Risk Analysis (CRA), Designating the regressed by Loan collection (LC), the independent variables by UCL, CRA, CRI, CM, CP, and (CRA) and the error- by $u$, the model is given by the following Equation as:

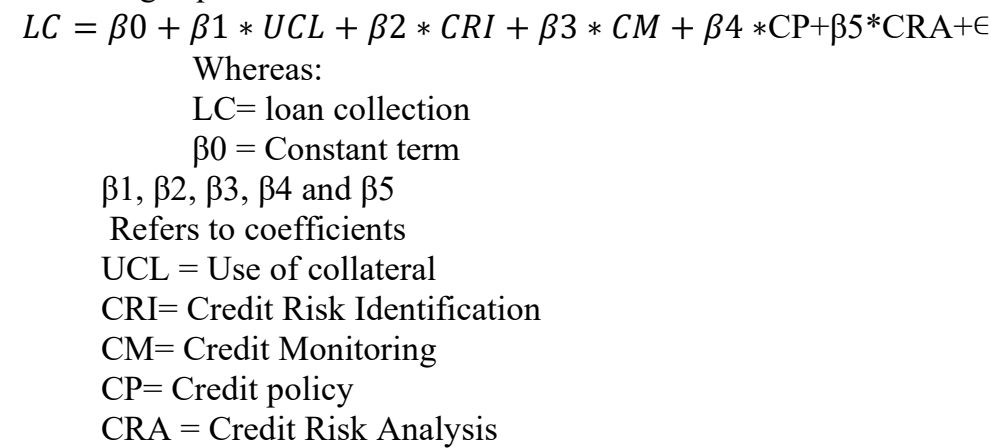




$$
\epsilon=\text { is error term }
$$

\subsection{Classical linear regression model Assumption}

The following diagnostic tests will be carried out to ensure that the suits the basic assumption of classical linear model. Among the assumption, the researcher will conducted four basic diagnostic tests to check if the data meet the requirement. Normality, Multicollinearity, autocorrelation, and heteroscedasticity tests were undertaken.

\subsection{Reliability and Validity Test}

Reliability Test: to measure the consistency of the questionnaire particularly the 5 point Likert- scale have developed by the researchers. To carry out the reliability analysis, Cronbach's Alpha $(\alpha)$ is the most common measure of scale reliability and a value greater than 0.70 is very acceptable. Data collected from pilot test was analyzed using SPSS (Statistical Package for Social Sciences) version 21.0.

Validity Test: The validity of the questionnaire was determined through face, content and constructs validity. First, the question was framed in such a manner that it was easily understood and exactly conveyed its sense and purpose to the respondents. Moreover, the draft questionnaire was given to 5 academic staff to view it in the light of the research objectives, its relevance, the adequacy of the questionnaire items, and question coverage.

\subsection{Methods of Data Analysis}

After accomplishment of data collection procedure, it was classified as per each variable; the qualitative data was coded to be measured quantitatively. In this research, the descriptive and inferential statistics of data analysis tool was employed and done by the help SPSS version 21.0 in order to get the reliable finding.

\subsection{Ethical Considerations}

The following ethical considerations have been given attention by the researchers while conducting the research. Conserving the voluntary participation of respondents, no participants were forced to take part in the research and participants were free to withdraw from the research at any moment. With regarding to harm to participants, the researcher ensured that there is no any physical or psychological harm done to the participants as a result of the study. When it comes to anonymity and confidentiality, all information gathered during the study has been handled confidentially and permission from the participants was obtained for all information to be shared publicly. Not deceiving the subjects since participants were informed clearly about the aim, purpose and procedures of the study and were not deceived in any way. Finally Privacy of participants the participants were respected.

\section{Results}

\subsection{Introduction}

In order to conduct data analysis, the researcher distributed one hundred fifteen (115) questionnaires to respondents. Out of the115 questionnaires distributed, 100 questionnaires were correctly filled and returned. This implies that the response rate of the research was $86.95 \%$ which implies almost all respondents have been participated in the process of data collection. Then, the descriptive statistical analysis has done using the statistical package for social science version 21.0 based on questionnaires properly collected.

\subsection{Reliability and Validity Test}

Reliability Test: To measure the consistency of the questionnaire particularly the Likert-type scale the reliability analysis is essential in reflecting the overall reliability of constructs that it is measuring. The test of reliability is the sound measurement.

\section{Table 4.1 Reliability Test}

Cronbach's Alpha

0.755

In current research, the researcher employed Cronbach's Alpha $(\alpha)$ which is the most common measure of scale reliability and a value greater than 0.7 is very acceptable. From table 2 above, the value for Cronbach's Alpha $(\alpha)$ was 0.895 for all variables which is more than minimum acceptable $(0.70)$. When these calculated reliability values for Cronbach's Alpha based on Standardized items is 0.897, which is also higher compared with the minimum value of alpha 0.70 . This implies that the data fitted in the SPSS is more reliable.

Validity Test: The validity of the questionnaire was determined through face, content and constructs validity. First, the question airs was framed in such a manner that it was easily understood and exactly conveyed its sense and purpose to the respondents. Moreover, the draft questionnaire was given to academic staff of the college to view it in the light of the research objectives, its relevance, the adequacy of the questionnaire items, and question coverage. 


\subsection{Descriptive Statistics}

Table 4.2: Summary of Descriptive Statistics for all Variables incorporated in the Model

\begin{tabular}{|l|r|r|r|r|r|}
\hline Variables & $\mathrm{N}$ & Minimum & Maximum & \multicolumn{1}{c|}{ Mean } & \multicolumn{1}{c|}{ Std. Deviation } \\
\hline Loan Collection & 100 & 1.00 & 5.00 & 2.6600 & 1.21622 \\
\hline Use of Collateral & 100 & 1.00 & 5.00 & 2.5900 & 1.11096 \\
\hline Credit Risk Identification & 100 & 1.00 & 5.00 & 3.0900 & 1.32646 \\
\hline Credit Monitoring & 100 & 1.00 & 5.00 & 3.2704 & .96783 \\
\hline Credit policy & 100 & 1.00 & 5.00 & 2.8200 & 1.25835 \\
\hline Credit Risk Analysis & 100 & 1.00 & 5.00 & 2.8700 & .97084 \\
\hline
\end{tabular}

Sources: Survey data (2020)

Loan collection (LC) was the dependent variable of this study. As indicated in the above table 4.2, the loan collection (LC) shows that MFIs on average is a positive loan collection because the overall mean of the variable was 2.6600 with a maximum of 5 and a minimum of 1 Likert scale values. The standard deviation value is 1.21622 which indicates there was variation of actual responses from the mean. With regard to other variables the use of collateral (CL) has the overall mean was 2.5900 with SD of 1.11096 , Credit risk identification (CRI) 3.0900 with SD of 1.32646, Credit monitoring (CM) 3.2704 high mean with SD of 0.96783, Credit policy (CP) 2.8200 with SD 1.25835, credit risk analysis (CRA) 2.8235with SD of 0.97084. In summary, all most all variables incorporated in the model have moderate contribution to the response variable loan collection of MFIs. We may not consider the interpretation of mean since they influenced by the extreme values.

\subsection{Pearson Correlation Matrix for Dependent and Independent Variables}

Correlation analysis measures the relationship between two items. The resulting value (called the "correlation coefficient) shows if changes in one item will result in changes in the other item. Correlation is a way to index the degree to which two or more variables are associated with or related to each other. The correlation matrix for this study was computed as follow:

Table 4:3: Pearson Correlation Matrix for Dependent and Independent Variables

\begin{tabular}{|c|c|c|c|c|c|c|c|}
\hline \multicolumn{2}{|l|}{ Variables } & \multirow{2}{*}{$\begin{array}{c}\begin{array}{c}\text { Loan } \\
\text { Collection }\end{array} \\
1\end{array}$} & \multirow{2}{*}{$\begin{array}{c}\begin{array}{c}\text { Use of } \\
\text { Collateral }\end{array} \\
.359^{* *}\end{array}$} & \multirow{2}{*}{$\begin{array}{c}\text { Credit Risk } \\
\text { Identification } \\
.163\end{array}$} & \multirow{2}{*}{$\begin{array}{c}\text { Credit } \\
\text { Monitoring } \\
.263^{* *}\end{array}$} & \multirow{2}{*}{$\begin{array}{l}\begin{array}{l}\text { Credit } \\
\text { policy }\end{array} \\
.362^{* *}\end{array}$} & \multirow{2}{*}{$\begin{array}{c}\begin{array}{c}\text { Credit } \\
\text { Risk } \\
\text { Analysis }\end{array} \\
.373^{* *}\end{array}$} \\
\hline $\begin{array}{l}\text { Loan } \\
\text { Collection }\end{array}$ & $\begin{array}{c}\text { Pearson } \\
\text { Correlation }\end{array}$ & & & & & & \\
\hline & Sig. (2-tailed) & & .000 & .105 & .008 & .000 & .000 \\
\hline & $\mathrm{N}$ & 100 & 100 & 100 & 100 & 100 & 100 \\
\hline \multirow[t]{3}{*}{$\begin{array}{l}\text { Use of } \\
\text { Collateral }\end{array}$} & $\begin{array}{c}\text { Pearson } \\
\text { Correlation }\end{array}$ & $.359^{* *}$ & 1 & $.279^{* *}$ & .141 & -.118 & $-.256^{*}$ \\
\hline & Sig. (2-tailed) & .000 & & .005 & .161 & .241 & .010 \\
\hline & $\mathrm{N}$ & 100 & 100 & 100 & 100 & 100 & 100 \\
\hline \multirow[t]{3}{*}{$\begin{array}{l}\text { Credit Risk } \\
\text { Identification }\end{array}$} & $\begin{array}{c}\text { Pearson } \\
\text { Correlation }\end{array}$ & .163 & $.279^{* *}$ & 1 & .071 & $-.438^{* *}$ & -.014 \\
\hline & Sig. (2-tailed) & .105 & .005 & & .482 & .000 & .887 \\
\hline & $\mathrm{N}$ & 100 & 100 & 100 & 100 & 100 & 100 \\
\hline \multirow[t]{3}{*}{$\begin{array}{l}\text { Credit } \\
\text { Monitoring }\end{array}$} & $\begin{array}{c}\text { Pearson } \\
\text { Correlation }\end{array}$ & $.263^{* *}$ & .141 & .071 & 1 & .054 & .027 \\
\hline & Sig. (2-tailed) & .008 & .161 & .482 & & .596 & .794 \\
\hline & $\mathrm{N}$ & 100 & 100 & 100 & 100 & 100 & 100 \\
\hline \multirow[t]{3}{*}{ Credit policy } & $\begin{array}{c}\text { Pearson } \\
\text { Correlation }\end{array}$ & $.362^{* *}$ & -.118 & $-.438^{* *}$ & .054 & 1 & $.402^{* *}$ \\
\hline & Sig. (2-tailed) & .000 & .241 & .000 & .596 & & .000 \\
\hline & $\mathrm{N}$ & 100 & 100 & 100 & 100 & 100 & 100 \\
\hline \multirow[t]{3}{*}{$\begin{array}{l}\text { Credit Risk } \\
\text { Analysis }\end{array}$} & $\begin{array}{c}\text { Pearson } \\
\text { Correlation }\end{array}$ & $.373^{* *}$ & $-.256^{*}$ & -.014 & .027 & $.402^{* *}$ & 1 \\
\hline & Sig. (2-tailed) & .000 & .010 & .887 & .794 & .000 & \\
\hline & $\mathrm{N}$ & 100 & 100 & 100 & 100 & 100 & 100 \\
\hline
\end{tabular}

**Correlation is significant at $1 \%$ significance level, * Correlation is significant at $5 \%$ significance level (two tailed). Source: Survey data (2020) 
The table 6 shows the relationship between dependent variable which is loan collection and independent variables with coefficient of correlation 1 indicates that each variable is perfectly correlated with each other. The result shows that, variables such as use of collateral, credit risk identification, credit monitoring, credit policy and credit risk analysis have positive relationship with loan collection and statistically significant respectively since pvalue is more than $1 \%$ level of significance since $p$-value is less than 0.01 . On other hand, credit risk identification has positive but statistically insignificant effect on loan collection.

\subsection{Assessment of Ordinary Least Square Assumptions}

Ordinary Least Squares (OLS) is the most common estimation method for linear models and that's true for a good reason. As long as your model satisfies the OLS assumptions for linear regression, we can rest easy knowing that we're getting the best possible estimates. The most common assumptions to be tested before running final regression result are normality, multicollinearity, autocorrelation, and heteroscedasticity.

Assessment of Normality Test: The Classical Linear Regression Model assumes that the error term is normally distributed with the mean of error being zero as positive error will offset the negative error. This assumption can be tested by looking at the distribution of residuals. This has shown as follow:

Figure 1: Assessment of Normality Test through Histogram and Normal probability plot

Histogram

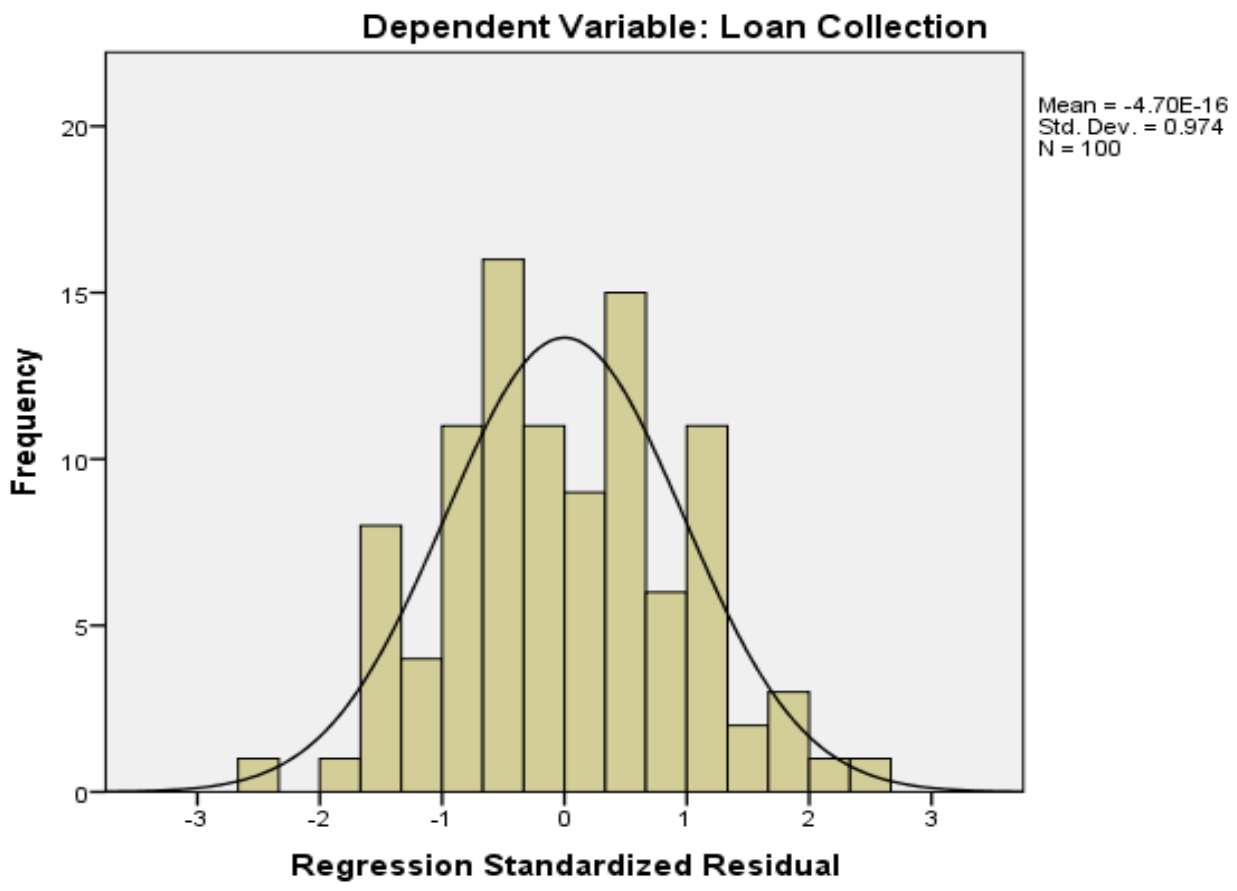

Source: Survey data (2020)

Based on the results shown above, the normal probability plot is linear to regression line and bell shaped histograms from SPSS. So, the researcher concluded that there is no normality problem on the data used for this study.

Assessment of Heteroscedasticity: Among the OLS assumptions one of the diagnostic tests conducted in this study is heteroscedasticity test (the variance of the residuals is constant). In the classical linear regression model, one of the basic assumptions is Homoscedasticity assumption that states as the probability distribution of the disturbance term remains same for all observations. That is the variance of each of disturbance term is the same for all values of the explanatory variable. However, if the disturbance terms do not have the same variance, this condition of non-constant variance or non-homogeneity of variance is known as heteroscedasticity. Accordingly, in order to detect the heteroscedasticity problems, regression plot the standardized values of the model would predict, against the standardized residuals obtained to test. 
Figure 2: Assessment of heteroscedasticity using Scatterplot plot Scatterplot

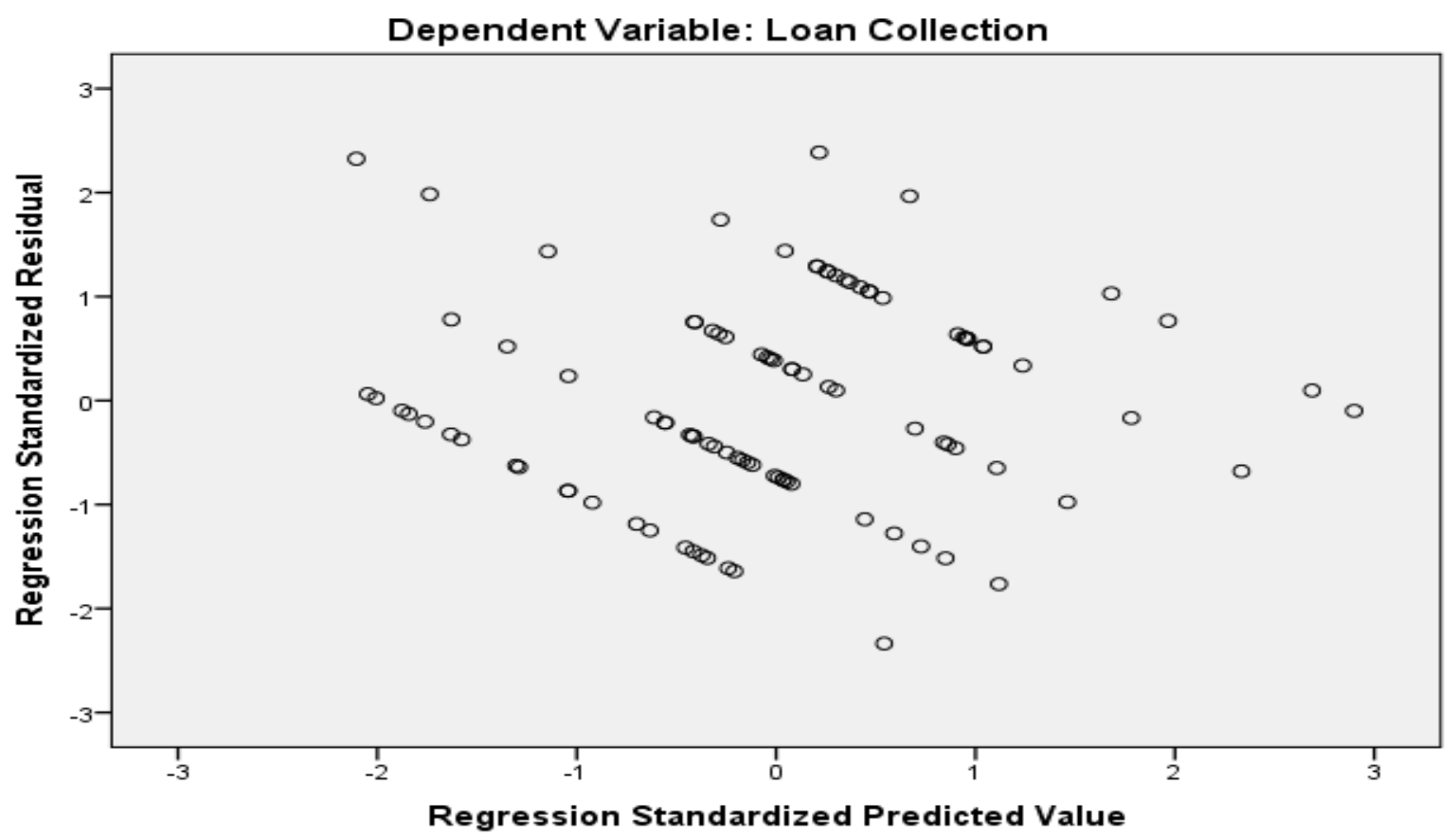

Source: Survey data (2020)

The above figure showed that accordingly, this is called homoscedasticity, and is the assumption that the variation in the residuals (or amount of error in the model) is similar at each point across the model. In other words, the spread of the residuals is fairly constant at each point of the predictor variables (or across the linear model).

Assessment of Multicollinearity: An implicit assumption that is made when using the panel least square estimation method is that the independent variables are not correlated with one another. If there is no relationship between the explanatory variables, they would be said to be orthogonal to one another. If the explanatory variables were orthogonal to one another, adding or removing a variable from a regression equation would not cause the values of the coefficients on the other variables to change. If an independent variable is an exact linear combination of the other independent variables, then we say the model suffers from perfect Collinearity, and it cannot be estimated by OLS. As shown in the Collinearity table 4.5 , the tolerance levels for all variables are greater than 0.10 and the VIF value are less than 10 . This indicates that there were no Multicollinearity problems that alter the analysis of the findings; rather it leads to the acceptance of R-value, tolerance and VIF values.

Table 4.4: Collinearity Statistics

\begin{tabular}{|l|c|c|}
\hline \multirow{2}{*}{\multicolumn{1}{|c|}{ Variables }} & \multicolumn{2}{c|}{ Collinearity statistics } \\
\cline { 2 - 3 } & Tolerance & VIF \\
\hline Use of Collateral & .828 & 1.207 \\
\hline Credit Risk Identification & .698 & 1.433 \\
\hline Credit Monitoring & .970 & 1.031 \\
\hline Credit policy & .635 & 1.574 \\
\hline Credit Risk Analysis & .735 & 1.360 \\
\hline
\end{tabular}

Source: Survey data, (2020)

As shown in the Collinearity table 4.5 , the tolerance levels for all variables are greater than 0.10 and the VIF value are less than 10 . This indicates that there were no multicollinearity problems that alter the analysis of the findings; rather it leads to the acceptance of R-value, tolerance and VIF values.

Assessment of Autocorrelation: this assumption can be tested with the Durbin-Watson test which test for serial correlation between errors and the value closer to 2 or more are acceptable. The Durbin-Watson statistics value are close to 2 or more suggests that there is no autocorrelation among error terms. Accordingly, the DurbinWatson statistics value of 1.922 which close to 2 indicates that autocorrelation is not a threat for the use of OLS in this study (see table 4.5). Therefore, it can be concluded that, the values of the residuals are independent which implies the absence of serial correlation problem in our regression analysis. 
4.6 The Regression Results (Inferential Statistics)

Table 4.5: Regression Results (LC) through SPSS

\begin{tabular}{|c|c|c|c|c|c|c|c|c|c|c|}
\hline \multirow{2}{*}{\multicolumn{2}{|c|}{ Model }} & \multicolumn{2}{|c|}{$\begin{array}{c}\text { Unstandardized } \\
\text { Coefficients }\end{array}$} & \multirow{2}{*}{$\begin{array}{c}\text { Standardized } \\
\text { Coefficients } \\
\text { Beta }\end{array}$} & \multirow[t]{2}{*}{$\mathrm{t}$} & \multirow[t]{2}{*}{ Sig. } & \multicolumn{2}{|c|}{$\begin{array}{c}95.0 \% \\
\text { Confidence } \\
\text { Interval for B }\end{array}$} & \multicolumn{2}{|c|}{$\begin{array}{l}\text { Collinearity } \\
\text { Statistics }\end{array}$} \\
\hline & & B & $\begin{array}{l}\text { Std. } \\
\text { Error }\end{array}$ & & & & $\begin{array}{l}\text { Lower } \\
\text { Bound }\end{array}$ & $\begin{array}{l}\text { Upper } \\
\text { Bound }\end{array}$ & Tolerance & VIF \\
\hline \multirow[t]{6}{*}{1} & (Constant) & -1.894 & .532 & & $\begin{array}{c}- \\
3.559\end{array}$ & .001 & -2.950 & -.837 & & \\
\hline & $\begin{array}{l}\text { Use of } \\
\text { Collateral }\end{array}$ & .447 & .090 & .408 & 4.970 & .000 & .268 & .626 & .828 & 1.207 \\
\hline & $\begin{array}{l}\text { Credit Risk } \\
\text { Identification }\end{array}$ & .181 & .082 & .198 & 2.208 & .030 & .018 & .344 & .698 & 1.433 \\
\hline & $\begin{array}{c}\text { Credit } \\
\text { Monitoring }\end{array}$ & .206 & .095 & .164 & 2.155 & .034 & .016 & .395 & .970 & 1.031 \\
\hline & Credit policy & .342 & .091 & .354 & 3.776 & .000 & .162 & .522 & .635 & 1.574 \\
\hline & $\begin{array}{l}\text { Credit Risk } \\
\text { Analysis }\end{array}$ & .418 & .109 & .333 & 3.823 & .000 & .201 & .634 & .735 & 1.360 \\
\hline
\end{tabular}

a. Dependent Variable: Loan Collection: $\mathrm{R}=.689, \mathrm{R} 2=.475$, Ad R2.447, Std. Error of the Estimate $=.90475$,

Durbin-Watson $(d)=1.922, \quad$ F-statistic $=16.979$, P-value $=0.000$, ANOVA with (p-value of 0.000

Source: Survey data, (2020)

Fitted Model

$\mathrm{LC}=-1.894+0.445 * \mathrm{UOC}+0.181 * \mathrm{CRI}+0.206 * \mathrm{CM}+0.342 * \mathrm{CP}+0.418 * \mathrm{CRI}+E$

The OLS result of was presented in the above table 4.7. R-squared was measured the goodness of fit of the explanatory variables in explaining the variations in loan collection effectiveness of Sidama Chalala credit and saving cooperatives. R-squared and the Adjusted-R- squared statistics of the model were 47.5 percent and 44.7 percent respectively. The result indicates that 44.7 percent variation in the dependent variable was jointly explained by the explanatory variables in the model. Whereas, the remaining 55.3 percent of the variation in the loan collection is explained by other variables which are not included in the model. The coefficient of explanatory variables such as use of collateral +0.447 , credit risk identification +0.181 , credit monitoring +0.206 , credit policy +0.342 and credit risk analysis +0.418 implies that $1 \%$ increase in the variables leads to $44.7 \%, 18.1 \%$, $20.6 \%, 15.8 \%, 34.2 \%$ and $41.8 \%$ increase in dependent variable ( loan collection) of MFIs. Besides, the, Fstatistics (16.979) in model summary and ANOVA with (p-value of 0.000) which is used to test the overall significance of the model was presented and indicates the reliability and validity of the model at 1 percent level of significance. This tells us that the model as a whole is statistically significant.

\subsection{Hypothesis Testing (Discussion)}

In addition more explanation of the model of this research, let us discus each variables incorporated in the model one by one. The result of this study shows that support from existence of collateral with unstandardized coefficient of regression $[\beta=0.447]$ has a positive and statistically significant at $1 \%$ level of significance since ( $\mathrm{p}$-value of $0.000<0.01$ ). Hence, hypothesis $\mathrm{H} 1$ is accepted. This finding is consistent with idea of study result by [3], [4]; [18] and [25] showed evidenced that there is positive relationship between collateral and loan collection of MFIs. This implies that more the usage of collateral is positively contributes to the success of loan collection.

The result of this study with regards to credit risk identification showed unstandardized coefficient of regression $[\beta=0.181]$ has positive and statistically significant at $5 \%$ level of significance since ( $p$-value of 0.030 $<0.01)$. Hence, the researcher accepted hypothesis H2. This finding is consistent the finding of other study result of 10], [21]; [23]; [23] and [25] who found out that credit risk identification has positive and significant effect on loan collection of MFIs. This implies that sound credit risk identification has positive contribution to the effective loan collection. Results indicated that the existence of credit monitoring procedures and effectiveness of loan collection had a positive and significant relationship. Consequently, the MFIs should work on credit risk identification which is the instrument for loan collection from borrowers.

Regarding to the credit monitoring $[\beta=0.206]$ is positive and statistically significant with $p$-value $(0.034>5 \%$, level of significance. Therefore, hypothesis $\mathrm{H}_{3}$ is accepted by the researcher. Hence, the existence of credit monitoring in an organization has positive effect on loan collection. This is consistent with the empirical studies [3], [4], [18], and [25]. Results indicated that the existence of credit monitoring procedures and effectiveness of loan collection had a positive and significant relationship. So, the MFIs should work on credit risk identification which tool for loan recovery from borrowers. Results indicated that the existence of credit monitoring procedures and effectiveness of loan collection had a positive and significant relationship. So, the MFIs should work on credit 
monitoring since the sound monitoring practice has positive effect on loan recovery from borrowers.

The result of this study also shows that coefficient of regression credit policy is $[\beta=0.342]$ positive and statistically significant since ( $\mathrm{p}$-value of $0.00<0.01$ and 0.05 ). Hence, hypothesis $\mathrm{H}_{4}$ is accepted. This finding is similar with findings of studies such as [3], [4], [11]; [18], [19], [20], [21] and [25] showed that existence of credit policy has positive and statistically effect on loan collection of MFIs. Results indicated that the existence of credit monitoring procedures and effectiveness of loan collection had a positive and significant relationship. As a result, the MFIs should work on credit policy which tool for loan recovery from debtors.

When comes to the credit risk analysis, unstandardized coefficient of regression of variable is $[\beta=0.418]$ is positive and statistically significant with p-value $\left(0.00>1 \%\right.$, level of significance. Therefore, hypothesis $\mathrm{H}_{6}$ is accepted by the researcher. This finding is consistent with the empirical result of empirical results [3], [4], [11]; [18], [19], [20], [21], [23], [25], [26], [27]; [28] and [29] result indicated that credit risk analysis has positive effect on loan collection. Results indicated that the existence of credit monitoring procedures has positive impact on loan collection. Thus, the MFIs should work on credit risk analysis because if credit risk is analyzed properly, it is easy to collect loan from debtors.

\section{Conclusions \& Recommendation}

Conclusion is the process of making generalization based on findings of sample to total population. This study aimed to identify the effect of credit provision practice on loan collection of MFIs in Sidama regional state. Therefore, the findings revealed from this study were generalized to all MFIs in Sidama regional state, Ethiopia: By keeping this objective in mind, the researcher collected the primary data through self-administrated or (structured) questionnaire. By using SPSS version 23.0 the analysis of both descriptive and inferential statistics has been done. Based on the findings from the descriptive analysis, the researchers had concluded that MFIs on average generated the loan collection. Based on the findings from the regression analysis of the model, the researchers concluded that the loan collection of MFIs is positive and significantly influenced by use of collateral, credit risk identification, credit monitoring, credit policy and credit risk analysis. The conclusion that can be drawn from the findings in the first hypothesis up to five hypotheses $(\mathrm{H} 1, \mathrm{H} 2, \mathrm{H} 3, \mathrm{H} 4$, and H5), stated as "collateral, credit risk identification, credit monitoring, credit policy and credit risk analysis has positive and significant effect on loan collection of MFIs were accepted. This means an increase one unit value the value of collateral, credit risk identification, credit monitoring, credit policy and credit risk analysis leads to increase in loan collection of MFIs. Then, the researcher forwarded the possible recommendations for MFIs to enhance the loan collection through improving credit provision practice by giving attention on the stated variables with statistically significant effect on loan collection of micro finance institutions in Sidama regional state, Ethiopia.

\section{Limitations \& Direction for the Future Research}

Any study cannot be free from limitations. Accordingly, there are some limitations in current study. So, this study is focused only on credit provision practice and its effect on loan collection with reference to MFIs in Sidama regional state.

The explanatory variables incorporated in the model have only explained $44.7 \%$ of the model. The remaining $55.3 \%$ of changes in the loan collection was explained by other explanatory variables that not included in the model. The other researcher should incorporate more variables to improve adjusted R2 with the same topic at the same study area. In other way, the findings of this study may be difficult to generalize about all MFIs in Ethiopia and all countries in Africa in particular and in the world in general. Hence, this study can be improved if it will be done at continental level.

\section{Acknowledgement}

First of all, I would like to give unlimited thanks for Almighty God for helping me capacity, knowledge and chance to complete this research paper. Next to God, I appreciate Furra College which is the top per-public higher education institutions in Ethiopia that striving to serve the community by providing trainings in both undergraduate and postgraduate programs in different fields and supporting problem solving research works thoroughly. Furra College is well known per-public institution in Ethiopia by free of charge community services for the whole public. In addition, I would like to express my heartfelt thanks to the managing director of the Furra Institute of Development Studies and Education Ato Addisu Abebe for initiating and appreciating my research work. Furthermore, I am grateful to Barassa Balguda dean of Furra College Gudamale Campus for encouraging my research activity. In the same way, I am happy to Mathewos Yure, vice academic dean of Furra College Gudamale Campus for inspiring my research work and being with me in any aspects. In addition, I would like to express our thanks to all staff of Furra College Gudamale, Yirgalem, and Alamura campuses. Last but not least, I also extend my heartfelt thanks to the editors and the anonymous reviewers for their guidance and constructive comments in developing this article. 


\section{References}

[1] Arrassen, Wassini, (2013). "La microfinance : quelles leçons tirées des expériences des pays en développement Economics Thesis from University Paris Dauphine, Paris Dauphine University, number 123456789/12692 edited by Avouyi-Dovi, Sanvi

[2] Adamu dama, Asongo A. Nyor N. (2014). Departments Credit Risk Portfolio Management in Microfinance Banks: Conceptual and Practical Insights. Universal Journal of Applied Science 2(6): 111-119.

[3] Alex. K. (2011). Credit Policy and Loan Recovery in Microfinance Institutions: Case of Blue Microfinance Institution Kisoro. In Partial Fulfilment for the Award of Bachelor of Commerce of Makerere University, Kampala.

[4] AJBE. (2018). The effect of credit collection policy on portfolio at risk of microfinance institutions in Tanzania. https://www.athensjournals.gr/reviews/2018-2723-AJBE.pdf. PP. 1-19

[5] Arnone, M., Pellegrini, C.B., Messa, A., Pellegrini, L. and Sironi, E. (2012) 'Microfinance institutions in Africa, Asia, and Latin America: an empirical analysis of operational efficiency, institutional context and costs', Int. J. Economic Policy in Emerging Economies, Vol. 5, No. 3, pp.255-271.

[6] Baklouti Ibtissem, Abdelfettah Bouri. (2013). Credit Risk Management In Microfinance: The Conceptual Framework. Journal of Development and Agricultural Economics Vol. 3(4), pp. 150-156

[7] Banerjee, S. B., \& Jackson, L. (2017). Microfinance and the business of poverty reduction: Critical perspectives from rural Bangladesh. Human Relations, 70(1), 63-91. https://doi.org/10.1177/0018726716640865

[8] Basu, A., \& Yulek, M. (2004). Microfinance in Africa: Experience and lessons from selected African countries. Retrieved from https://papers.ssrn.com/sol3/papers.cfm?abstract_id=878999

[9 Beck, T. (2015). IEG working Paper: Microfinance a critical literature survey:The World Bank Group.

[10] Chirkos, A. Y. (2014). The Role of Microfinance Institutions in the Development of Small and Medium Size Businesses in Ethiopia, A Case Study in Amhara Credit and Saving Institutions. Journal of Business Administration and Management Sciences Research, 5(13), 106-120.

[11] Glisovic, J., \& Martinez, M. (2012). Financing Small Enterprises: What Role for Microfinance Institutions? Cgap, 81(Ifc 2010), 16

[12] Fasika Firew .(2012). has investigated selected Ethiopian commercial banks operational risk management.

[13] Hamilton, S. M., Liddell, L., Young, M., Shaw, P., Gacia, A., Khan, A., \& Srivastava, A. (2008). Microfinance Institutions - Factors in Risk Assessment. Fitch Rating, Criteria Report, (June), 1-15.

[14] Harper, M. (2012). Beyond micro-credit: Putting development back into micro-finance. Retrievedfromhttps://books.google.com/books?hl=en\&lr=\&id=jfBnBtxmPUwC\&oi=fnd\&pg=PA9\&ots=Cs gZs2XfZf\&sig=6dSXi0Z4BifRlkeHYR3RhQ-yZHQ

[15] Helms, B. (2006). Access for all: building inclusive financial systems. Retrieved from https://elibrary.worldbank.org/doi/abs/10.1596/978-0-8213-6360-7

[16] Mathewos Yure Dangisso, Kanbiro Orkaido Deyganto. Assessing the Institutional Outreach and Sustainability of Micro Finance Institutions in Ethiopia: Evidence from Omo Microfinance Institution Hawassa Branch. American Journal of Theoretical and Applied Business. Vol. 6, No. 1, 2020, pp. 1-5. doi: 10.11648/j.ajtab.20200601.11

[17] Morduch, J., \& Armendáriz, B. (2010). The Economics of Microfinance. (2nd Ed.) MIT Press.

[18] Muthoni. M. P. (2016). Assessing Borrower's and Business' Factors Causing Microcredit Default in Kenya: A Comparative Analysis of Microfinance Institutions and Financial Intermediaries. Journal of Education and Practice.Vol.7, No.12. PP. 97-118

[19] Nada Milenkovic, M. P. \& S. O. (2011). Analysis of Credit Risk Based on Financial Statements As the Decisive Factor Influencing the. International Symposium Engineering Management and Competitiveness, $2011,233-238$

[20] Otieno, \& Omondi, S. (2013). Assessment of the Impact of Microfinance on the Growth of Small Businesses in Kisumu Municipality , Kenya By Otieno Samuel Omondi a Research Project Report Submitted in Partial Fulfillment of the Requirement for the Award of a Degree of Master of Business.

[21] Peter Kitonga. (2014). Determinants of Effective Debt Collection in Commercial Banks in Kenya. A Research Project Submitted to the Chandaria School of Business in Partial Fulfillment of the requirement for the Degree of Masters of Business Administration (MBA) to United States International University

[22] Rozzani, N., Mohamed, I. S., \& Syed Yusuf, S. N. (2017). Risk management process: Profiling of islamic microfinance providers. Research in International Business and Finance, 41, $20-27$. https://doi.org/10.1016/j.ribaf.2017.04.009

[23] Sharma, A.K, Sharma, D. and Barua, M.K., .(2012). Efficiency and productivity of Indian banks: an application of data envelopment analysis and Tobit regression, National Conference on Emerging Challenges for Sustainable Business, India. (Vasavada, Kumar, Rao\&Pai,2005).

[25] Tekilu .(2020.) The Effect Of Credit Risk Management On Loan Collection Effectiveness Of Selected Rural Saving And Credit Cooperatives: The Case Of Sidama Chalala Saving And Credit Cooperative Union. MSC 
thesis Unpublished

[26] Tsion Fekede selasse .(2015). has studied on Risk Management Practice of Ethiopian Commercial Banks.

[27] Tchouassi. G. (2011). Microfinance, inequality and vulnerability: Empirical analysis from Central African countries. Journal of Development and Agricultural Economics Vol. 3(4), pp. 150-156

[28]Wikipedia. (2019). General Information about Microfinance. Available On Https://En.Wikipedia.Org/Wiki/Microfinance Accessed On March 14, 2020

[29] Yebabie Yoseph. (2017).Assessment of Credit Risk Management in Micro Finance Institutions. (In the case of Addis credit and saving institutions). MBA thesis 